\title{
PENERAPAN MANAJEMEN RISIKO SEBAGAI PRINSIP KEHATI-HATIAN DALAM PEMBERIAN KREDIT PERBANKAN
}

\author{
Etty Mulyati \\ Universitas Padjajaran, Bandung \\ Ettymulyati@gmail.com
}

\begin{abstract}
Abstrak
Kredit yang dikeluarkan oieh bank mengandung resiko sehingga dalam pelaksanaannya setiap pemberian kredit bank harus memperhatikan prinsip kehati-hatian dan asas perbankan yang sehat, baik secara internal maupun secara ekstemal.Imlementasi prinsip kehati-hatian secara internal bagi Sumber Daya Manusia (SDM) bank adalah dengan menerapkan Prinsip Manajemen Risiko. Permasalahannya adalah bagaimana penerapan manajemen risiko dalam pemberian kredit perbankan serta kendala dalam menerapkan manajemen risiko. Penerapan manajemen risiko pada pemberian kredit mencakup pengawasan aktif Direksi dan Dewan Komisaris, kecukupan kebijakan dan prosedur Manajemen Risiko serta penetapan limit Risiko dan kecukupan proses identifikasi, pengukuran, pemantauan, pengendalian Risiko, serta sistem informasi Manajemen Risiko dan sistem pengendalian intern yang menyeluruh. Penyaluran kredit merupakan sumber timbulnya risiko kredit yang paling besar, risiko terkait dengan penyaluran kredit yaitu risiko kredit, risiko operasional, risiko hukum, dan risiko reputasi. Kendala dalam penerapan manajemen risiko Perbankan, antara lain SDM yang terlibat dalam pemantauan penerapan manajemen risiko masih relatif kurang siap.
\end{abstract}

Kata kunci: bank, kredit, manajemen risiko, prinsip kehati-hatian.

\begin{abstract}
Loans incurred by the bank carry risks so that in the implementation of each bank lending must pay attention to prudential principles and sound banking principles, both internally and externally. Implementation ofprudential principles internally for the Bank's Human Resources is to apply Risk Management Principles. The problem is how the implementation of risk management in the provision of bank credit and obstacles in applying risk management. The implementation of risk management in lending involves the active supervision of the Board of Directors and the Board of Commissioners, the adequacy of Risk Management policies and procedures and the determination of the Risk and Adequacy Risk Monitoring process, risk measurement, monitoring, and risk management as well as Risk Management information system and comprehensive internal control system. Loan disbursement is the largest source of credit risk, the risks associated with lending are credit risk, operational risk, legal risk, and reputation risk. Constraints in the application of risk management Banking, among others, human resources involved in monitoring the implementation of risk management is still relatively poorly prepared.
\end{abstract}

Keywords: bank, credit, prudential principles, risk management 


\section{Pendahuluan}

Pembangunan Nasional sebagai rangkaian upaya pembangunan yang berkesinambungan meliputi seluruh kehidupan masyarakat, bangsa dan negara untuk melaksanakan tugas mewujudkan tujuan nasional yang termaktub dalam pembukaan UUD NRI Tahun 1945, yaitu melindungi segenap bangsa dan seluruh tumpah darah Indonesia, memajukan kesejahteraan umum, mencerdaskan kehidupan bangsa, serta ikut melaksanakan ketertiban dunia yang berdasarkan kemerdekaan, perdamaian abadi dan keadilan sosial.

Pemberdayaan masyarakat dan seluruh kekuatan ekonomi nasional dalam pembangunan di bidang ekonomi merupakan suatu langkah yang baik, mengingat pembangunan memerlukan adanya ketersediaan dana dalam jumlah besar yang menuntut adanya peran serta segenap komponen bangsa untuk ikut berpartisipasi dalam kegiatan pembangunan, sehingga memunculkan suatu mekanisme perputaran dana dari dan untuk masyarakat yang dikelola oleh suatu lembaga keuangan dalam hal ini lembaga keuangan bank.

Bank merupakan bagian dari lembaga keuangan yang memiliki fungsi intermediasi yang menjembatani kepentingan pihak yang kelebihan dana (kreditur) dan pihak yang membutuhkan dana (debitur). Berdasarkan fungsinya ini bank disebut sebagai lembaga intermediasi atau lembaga perantara. Disamping mempunyai fungsi umum tersebut juga mempunyai fungsi khusus yaitu diarahkan sebagai agen pembangunan (agent of development), yaitu sebagai lembaga yang bertujuan mendukung pelaksanaan pembangunan dan hasil-hasilnya, pertumbuhan ekonomi dan stabilitas nasional kearah peningkatan taraf hidup rakyat banyak (Hermansyah, 2007:41). Bank merupakan bagian dari lembaga keuangan yang memiliki fungsi intermediasi yang menjembatani kepentingan pihak yang kelebihan dana (kreditur) dan pihak yang membutuhkan dana (debitur). Berdasarkan fungsinya ini bank disebut sebagai lembaga intermediasi atau lembaga perantara.

Bank dalam menyalurkan dananya antara lain melalui pemberian kredit adalah merupakan salah satu sumber dana bagi pembangunan, karena berputarnya roda dunia usaha sangat tergantung kepada kredit yang dikeluarkan oleh bank yang akan dipergunakan sebagai modal untuk berusaha, hal ini terbukti ketika beberapa tahun belakangan ini dunia perbankan dilanda keterpurukan sehingga menimbulkan dampak banyaknya pengusaha yang mengalami kesulitan ekonomi.

Kredit yang dikeluarkan oleh bank mengandung resiko sehingga dalam pelaksanaannya bank harus memperhatikan asas-asas perkreditan yang sehat, diantaranya yaitu (Muhamad Djuhamna, 2000:392):

a. Bank tidak diperkenankan memberikan kredit tanpa surat perjanjian tertulis.

b. Bank tidak diperkenankan memberikan kredit kepada usaha yang sejak semula telah diperhitungkan kurang sehat dan akan menimbulkan kerugian.

c. Bank tidak diperkenankan memberikan kredit untuk pembelian saham dan modal kerja dalam jual beli saham atau 
d. Memberikan kredit melampaui batas maksimum pemberian kredit.

Setiap pemberian kredit bank harus memperhatikan prinsip kehati-hatian dan asas perbankan yang sehat, baik secara internal maupun secara eksternal. Secara eksternal sebelum dibuat perjanjian kredit bank selalu melakukan penilaian dari berbagai aspek, dengan menerapkan ketentuan Pasal 8 dan penjelasannya dalam Undang-undang Perbankan, bank wajib mempunyai keyakinan akan kemampuan debitur untuk mengembalikan kredit pada waktunya, seperti yang telah diperjanjikan, ketentuan tentang jaminan ini secara materiil lebih mengarah kepada jaminan secara ekonomis. Praktik perbankan biasanya melakukan penilaian terhadap lima aspek kepada debitur (analisis the five C's) yaitu: watak (character), modal (Capital), kemampuan (capacity), kondisi ekonomi (condition of economic) dan jaminan (collateral).

Implementasi prinsip kehati-hatian secara internal bagi Sumber Daya Manusia (SDM) bank adalah dengan menerapkan Prinsip Manajemen Risiko Perbankan. Perbankan Indonesia terus mengalami perubahan bentuk dan karakter secara signifikan. Kebijakan-kebijakan otoritas perbankan, tekanan kompetisi dalam pasar perbankan dan keuangan serta tuntutan kinerja dan efisiensi bisnis dari para stakeholders yang semakin dinamis menyebabkan bank harus dikelola secara proaktif terhadap kondisi dan potensi bisnis.

Esensi dari penerapan manajemen risiko adalah kecukupan prosedur dan metodologi pengelolaan risiko sehingga kegiatan usaha bank tetap dapat terkendali pada batas/limit yang dapat diterima serta menguntungkan bank. Namun demikian mengingat perbedaan kondisi pasar dan struktur, ukuran serta kompleksitas usaha bank, maka tidak terdapat satu sistem manajemen risiko yang universal untuk seluruh bank sehingga setiap bank harus membangun sistem manajemen risiko sesuai dengan fungsi dan organisasi manajemen risiko pada bank.

Pengaturan prinsip manajemen risiko perbankan di Indonesia, melalui Bank Indonesia sebagai regulator perbankan Indonesia telah memberikan arahan mengenai komitmen untuk pengelolaan risiko melalui Peraturan Bank Indonesia (PBI) No 2/27/PBI/2000, tgl 15 Desember 2000, yang diantaranya menetapkan kewajiban bagi bank-bank untuk memiliki pedoman manajemen risiko, petunjuk yang lebih jelas mengenai kerangka kerja manajemen risiko yang dimaksud baru disampaikan beberapa tahun kemudian melalui PBI No 5/8/PBI/2003 sebagaimana diubah dengan PBI No. 11/25/PBI/2009 tentang Penerapan Manajemen Risiko di Bank Umum (selanjutnya disebut PBI tentang Manajemen Risiko). Selama kurun 7 vaktu tersebut perbankan di Indonesia mengembangkan prinsip dan sistem manajemen risiko dengan berpedoman kepada best practice internasional yang disesuaikan dengan kebutuhan masing-masing bank.

Peraturan Otoritas Jasa Keuangan Nomor 18/POJK.03/2016 tentang Penerapan Manajemen Risiko bagi Bank Umum (Lembaran Negara Republik Indonesia Tahun 2016 Nomor 53, Tambahan Lembaran Negara Republik Indonesia Nomor 5861). Dalam pertimbangannya bahwa situasi lingkungan eksternal dan internal perbankan mengalami perkembangan pesat yang akan diikuti oleh semakin kompleksnya risiko bagi kegiatan usaha perbankan tersebut semakin kompleksnya risiko bagi kegiatan usaha perbankan alcan meningkatkan kebutuhan praktik tata kelola yang baik (good governance) serta fungsi identifikasi, pengukuran, pemantauan, dan pengendalian risiko bank. Peningkatan fungsi identifikasi, pengukuran, pemantauan, dan pengendalian risiko dimaksudkan agar aktivitas usaha yang dilakukan oleh bank tidak menimbulkan kerugian yang melebihi kemampuan bank atau yang dapat mengganggu kelangsungan usaha bank. Pengelolaan setiap aktivitas fungsional bank harus sedapat mungkin terintegrasi ke dalam suatu sistem dan proses pengelolaan risiko yang akurat dan komprehensif. 
Dalam rangka menciptakan prakondisi dan infrastruktur pengelolaan risiko, bank wajib mengambil langkah-langkah persiapan pelaksanaan pengelolaan risikonya, transparansi merupakan salah satu aspek yang perlu diperhatikan dalam pengendalian risiko yang dihadapi bank. Dengan demikian peningkatan kualitas penerapan manajemen risiko akan mendukung efektivitas kerangka pengawasan bank berbasis risiko.

Keberadaan Manajemen Risiko sangatlah penting dalam dunia perbankan. Terdapat kegagalan-kegagalan yang terjadi pada dunia perbankan di Indonesia akibat kegagalan dalam menerapkan manajemen risiko, seperti risiko yang pernah terjadi pada krisis moneter tahun 1997 ketika itu beberapa mengalami kegagalan usaha yang pada akhirnya dilikuidasi.

Ketidak mampuan bank dalam membayar kewajibannya yang dapat menghancurkan tidak saja pemegang saham bank, tetapi juga menghancurkan pihak ketiga yang menempatkan dana pada bank tersebut, hal ini merupakan risiko insolvensi yang bersumber dari terjadinya penuiunan drastis nilai asset bank yang menyebabkan turunnya permodalan bank yang tidak mampu meng-offset-nya (Masyud Ali, 2004:28). Oleh karena itu diperlukan keseriusan dan konsisten dalam melakukan manajemen risiko bagi perbankan di Indonesia. Keseriusan terhadap hal tersebutlah yang mendasari Bank Indonesia sebagai otoritas moneter yang memiliki tugas mengatur dan mengawasi bank, menetapkan produk-produk hukum berkaitan dengan manajemen risiko (Ferry N. Idroes, 2006:52-53). Kegiatan usaha Bank selalu dihadapkan pada risiko-risiko, terutama risiko dalam pemberian kredit yang mempunyai dampak cukup besar bagi kelangsungan usaha bank.

\section{B. Rumusan Masalah}

Berdasarkan latar belakang yang dikemukakan tersebut, permasalahnya adalah :

a. Bagaimana penerapan manajemen risiko pada pemberian kredit Perbankan sebagai prinsip kehati-hatian bank?

b. Bagaimana kendala dalam penerapan manajemen risiko Perbankan?

\section{Tujuan}

a. Untuk menganalisis penerapan manajemen risiko pada pemberian kredit Perbankan sebagai prinsip kehati-hatian bank.

b. Untuk mengetahui kendala dalam penerapan manajemen risiko Perbankan 


\section{Tinjauan Pustaka}

\section{A. Prinsip Kehati-hatian Bank terhadap Perjanjian Kredit Perbankan.}

Perbankan memegang peranan yang sangat penting sebagai suatu lembaga keuangan pemberi kredit, kredit merupakan kegiatan usaha bank yang paling utama. Istilah kredit sendiri berasal dari bahasa Romawi credere yang berarti percaya atau credo atau creditum yang berarti saya percaya. Jadi seseorang yang mendapatkan kredit adalah seseorang yang telah mendapatkan kepercayaan dari kreditur (Mariam Darns Badrulzaman, 1983:21). Berdasarkan ketentuan umum Pasal 1 ayat 11 Undang-undang Nomor 7 Tahun 1992 sebagaimana di ubah dengan Undangundang Nomor 10 Tahun 1998 Tentang Perbankan yang dimaksud dengan kredit adalah: "Kredit adalah penyediaan uang atau tagihan yang dapat dipersamakan dengan itu, berdasarkan persetujuan atau kesepakatan pinjam meminjam antara bank dengan pihak lain yang mewajibkan pihak peminjam untuk melunasi utangnya setelah jangka waktu tertentu dengan pemberian bunga". Intisari dari pemberian kredit oleh bank adalah karena adanya kepercayaan setelah dilakukan analisis yang mendalam terhadap itikad baik dan kemampuan serta kesanggupan calon debitur untuk melunasi utangnya sesuai dengan yang dip eijanj ikannya.

Pemberian Kredit berarti memberikan kepercayaan kepada debitur oleh kreditur meskipun kepercayaan tersebut mengandung risiko yang tinggi, dari uraian diatas dapat ditemukan unsurunsur yang terdapat didalam kredit, yakni (Hasanuddin Rahman, 1995:107):

a. Kepercayaan, yaitu keyakinan pemberi kredit bahwa kredit yang akan diterima kembali jangka waktu yang diperjanjikan.

b. Waktu, yaitu jangka waktu antara masa pemberian kredit dan masa pengembalian kredit, terkandung arti bahwa nilai uang pada waktu pemberian kredit adalah lebih tinggi daripada nilai uang yang akan diterima pada waktu pengembalian kredit dikemudian hari.

c. Degree of Risk, yaitu adanya tingkat risiko yang akan dihadapi sebagai jangka waktu yang memisahkan antara pemberian kredit dan pengembalian kredit berarti makin tinggi pula tingkat risikonya, karena ada unsur risiko ini maka suatu perjanjian kredit perlu suatu jaminan.

d. Prestasi yang diberikan adalah suatu prestasi yang dapat berupa barang-barang jasa atau uang. Dalam perkembangan perkreditan di alam modem maka yang dimaksud dengan prestasi dalam pemberian kredit adalah uang.

Tujuan kehati-hatian tidak lain agar bank selalu dalam keadaan sehat, dengan kata lain agar selalu dalam keadaan liquid dan solvent. Melalui perberlakuan prinsip kehati- hatian, diharapkan kadar kepercayaan masyarakat terhadap perbankan tetap tinggi, sehingga masyarakat bersedia dan tidak ragu-ragu menyimpan dananya di bank.

Kewajiban untuk menerapkan prinsip kehati-hatian khususnya dalam pemberian kredit tercantum dalam Pasal 8 (1) Undang-Undang Perbankan yaitu: "Dalam memberikan kredit atau pembiayaan berasarkan Prinsip Syariah, Bank Umum wajib

mempunyai keyakinan berdasarkan analisis yang mendalam atau itikad dan kemampuan serta kesanggupan nasabah debitur untuk melunasi utangnya atau mengembalikan pembiayaan dimaksud sesuai dengan yang diperjanjikan", Selanjutnya dalam penjelasan Pasal 8 ayat (1) adalah: "Kredit atau pembiayaan berdasarkan Prinsip Syariah yang diberikan oleh bank mengandung risiko, sehingga dalam pelaksanaannya bank harus memperhatikan asas-asas perkreditan atau pembiayaan berdasarkan Prinsip Syariah yang sehat. Untuk mengurangi risiko tersebut, jaminan pemberian kredit atau 
pembiayaan berdasarkan Prinsip Syariah dalam arti keyakinan atas kemampuan dan kesanggupan Nasabah debitur untuk melunasi kewajibannya sesuai dengan yang diperjanjikan merupakan faktor penting yang harus diperhatikan oleh bank.Untuk memperoleh keyakinan tersebut, sebelum memberikan kredit, bank harus melakukan penilaian yang seksama terhadap watak, kemampuan, modal, agunan, dana prospek usaha dari Nasabah debitur"

Sebagaimana Pasal 8 Undang-Undang Perbankan menyebutkan bahwa sebelum memberikan kredit, bank harus melakukan penilaian yang seksama, mengingat sumber dana kredit yang disalurkan adalah bukan dana dari bank itu sendiri, tetapi dana yang berasal dari masyarakat sehingga perlu menerapkan prinsip kehati-hatian melalui analisa yang akurat dan mendalam, penyaluran yang tepat sasaran dan memenuhi syarat hukum, pengikatan jaminan yang secara yuridis formal sesuai dengan ketentuan hukum dan perundang-undangan tentang jaminan, pengawasan dan pemantauan yang baik, perjanjian yang sah dan dokumentasi perkreditan yang teratur dan lengkap. Semuanya itu bertujuan agar kredit yang disalurkan tersebut dapat kembali tepat pada waktunya sesuai dengan perjanjian kredit meliputi pinjaman pokok dan bunga.

Dasar pemberian kredit yang sehat, dalam praktik setiap pemberian kredit bank wajib melakukan penilaian dari berbagai aspek, dengan menggunakan prinsip kehati- hatian yang dikenal prudential banking principles yang implementasinya dengan The Five C's of Credit Analysis (prinsip 5 C), berdasarkan Penjelasan Pasal 8 Undang- undang Perbankan antara lain meliputi:

1. Watak debitur (character), watak atau kepribadian debitur merupakan suatu unsur penting dalam pemberian kredit, yang dimaksudkan dengan watak adalah pribadi yang baik dari calon debitur, yaitu mereka yang selalu menepati janjinya dan berupaya mencegah perbuatan yang tercela, Debitur yang demikian mampu untuk mengembalikan kredit seperti yang dipeijanjikan. Kemampuan calon debitur (capacity), dalam mengelola usahanya harus diketahui secara pasti oleh pihak bank dari kemampuan manajemennya dan sumber daya manusianya, apakah ia mampu berproduksi dengan baik yang dapat dilihat dari kapasitas produksinya.

2. Modal debitur (Capital), untuk memperoleh kredit calon debitur harus memiliki modal terlebih dahulu, jumlah dan struktur modal calon debitur harus dapat diteliti dan diketahui tingkat rasio dan solvabilitasnya.Bank tidak dapat memberikan kredit kepada pengusaha tanpa modal sama sekali. Permodalan dan kemampuan keuangan dari debitur akan mempunyai korelasi langsung dengan tingkat kemampuan membayar kredit (Mahmoedin, 1995). 
3. Jaminan ('collateral) Jaminan dalam istilah perbankan disebut objek jaminan. Jaminan biasanya diartikan dengan harta benda milik debitor yang dijadikan jaminan atas piutangnya. Kredit senantiasa dibayangi oleh risiko, untuk berjaga-jaga timbulnya risiko ini diperlukan benteng untuk menyelamatkan yaitu jaminan sebagai sarana pengaman atas risiko yang mungkin timbul atas cidera janjinya nasabah dikemudian hari.

4. Kondisi ekonomi (condition of economic), kondisi atau situasi yang memberikan dampak positif kepada usaha calon debitur atau sebagaimana disebutkan dalam penjelasan Pasal 8 Undang-undang Perbankan yaitu hubungan faktor ekonomi makro terhadap risiko produknya. Kondisi ekonomi secara umum serta kondisi pada sektor usaha si pememohon kredit perlu mendapat perhatian dari pihak bank untuk memperkecil risiko yang mungkin timbul akibat kondisi ekonomi.

5. Karakter yang baik dari seseorang yang jujur secara moril bisa dipercaya dan mampu mengolah perusahaan yang dapat dilihat dari dari kemampuan manajemennya, apakah ia mampu berproduksi dengan dengan baik dilihat dri kapasitas produksinya. Penilaian kapasitas seseorang disasarkan pada pengalaman dalam dunia bisnis yang dihubungkan dengan pendidikan serta kekuatan perusahaan dan kemampuan penyesuaian diri dengan perkembangan teknologi. Permodalan dan kemampuan keuangan dari debitor mempunyai korelasi langsung dengan tingkat kemampuan membayar.

Di samping analisa $5 \mathrm{C}$ sebagai implementasi dari prinsip kehati-hatian dalam pemberian kredit adalah dengan prinsip 7P, meliputi (Kasmir, 2000):

1. Personality, yaitu penilaian nasabah dari segi kepribadiannya atau tingkah laku sehari-hari maupun masa lalunya. Personality juga mencakup sikap, emosi, tingkah laku dan tindakan nasabah dalam menghadapi suatu masalah.

2. Para pihak (party), yaitu mengklasifikasikan nasabah kedalam klasifikasi tertentu atau golongan-golongan tertentu berdasarkan modal, loyalitas serta karakternya, sehingga nasabah dapat digolongkan kegolongan tertentu dan akan mendapatkan fasilitas yang berbeda dari bank.

3. Tujuan (purpose), maksudnya analisis tentang tujuan penggunaan kredit yang telah disampaikan oleh calon debitur. Tujuan pengambilan kredit dapat bermacam-macam, misalnya untuk modal kerja atau investasi, dan lain sebagainya.

4. Prospek (prospect), yaitu untuk menilai usaha nasabah dimasa yang akan datang menguntungkan atau tidak, dengan kata lain mempunyai prospek atau sebaliknya hal ini penting mengingat jika suatu fasilitas kredit yang dibiayai tanpa mempunyai prospek bukan hanya bank yang rugi akan tetapi nasabahnya juga.

5. Pembayaran (payment), artinya sumber pembayaran dari calon debitur, hal ini merupakan ukuran bagaimana cara nasabah mengembalikian kredit yang telah diambil atau dari sumber mana saja dana untuk pengembalian kredit. Semakin banyak sumber penghasilan debitur maka akan semakin baik, sehingga jika salah satu usahanya merugi akan dapat ditutupi oleh sektor lainnya. 
6. Perolehan laba (profitability), yaitu penilaian, terhadap kemampuan calon debitui' untuk memperoleh keuntungan, dalam usahanya. Profitability di likur dari pei'iode apakah akan tetap sama atau semakin meningkat, apalagi dengan tambahan kredit yang akan diperolehnya.

7. Pei'lindungan. (protectiori) merupakan analisis terhadap sarana perlindungan terhadap kreditur. Tujuannya adalah bagaimana menjaga agar, usaha dan jaminan mendapatkan perlindungan, perlindimgan dapat berupa jaminan, barang atau orang atau jaminan asuransi.

\section{B. Pengaturan Penerapan Manajemen Risiko Bagi Bank Umum}

Manajemen risiko merupakan proses antisipasi terhadap risiko agar kerugian tidak terjadi, BI telah menegaskan komitmennya untuk mengeluarkan ketentuan-ketentuan yarrg didorong penerapan manajemen risiko perbankan yan.g sesuai dengan bestpractice internasional ö̈\#A memauk. I I I'o iieukv Bankfor International Settlenrents mdli Basle Conunittee on Banking Super Idsion.

Bank Indonesia (BI) menetapkan kewajiban bagi bank-bank untuk memiliki pedoman manajemen risiko, pelunjuk yan.g le'bih jelas mengenai kerangka kerja manajemen risiko yang dimaksud baru disampaikan beberapa talrun kemudian melalui PBI No 5/8/PBI/2003 sebagaimana diubah dengan PBI No. 11/25/PBI/2009 tentang Perrerapan Manajemen Risiko di Bank Umum (selanjutnya disebut PBI terrtang Manajemen Risiko). Selama kurun waktu tersebut perbankan di Irrdorresia mengembangkan prinsip dan sistem manajemen, risiko dengan berpedoman kepada best practice internasional yang disesuaikan dengan kebutuhan masing-masing barrk. Prinsipprinsip tersebut pada dasarnya merupakan standar bagi dunia perbankan urrhrk dapat beroperasi secara lebih berhati-hati dalam .tuang lingkup perkembangan kegiatan usaha darr operasional perbankan yang pesat dewasa ini.

Setelah pengaturan dan pengawasan bank beralih kepada Otoritas Jasa Keuangan sejak 31 Desember 2013, sesuai amanat Undang-Undang Nomor 21 tahun 2011 tentang Otoritas Jasa Keuangan (OJK). Pengaturan dan pengawasan bank dilakukan OJK, dengan demikian BI akan fokus pada pengendalian inflasi dan stabilitas moneter. Dalam meningkatkan frrngsi pengawasan terhadap perbankan OJK merencanakan untuk melakukan penaatan manajemen risiko, yang kemudian terbitlah Peraturan Otoritas Jasa Keuangan Nonror 18 /POJK.03/2016 Tentang Peirerapan Manajemen Risiko Bagi Bank Umum. Dengan berlakunya POJK ini maka PBI tentang Manajamen risiko tidak berlaku lagi. Sedangkan yang dimaksud dengan Manajemen Risi.ko Pasal 1 angka 3 POJK tentang Manajemen Risi.ko adalah serangkaian prosedur, dan nretodologi yang digunakan rrntuk mengidentifikasi, mengukur, memantau dan mengendalikan risiko yang timbul dari kegiatan usaha bank.

Da'lam dunia bisnis risiko selalu ada, tidak ada bisnis yang tidak ada risiko, selringga setiap saat harus bisa menanggung risiko, dengan cara meminimalisir- risiko. Risiko tidak cukup dihindari tapi harus dihadapi dengan cara-cara yang dapat memperkecil kemungkinan terjadinya suatu kerugian. Bank yang memiliki ukuran dan kompleksitas usalra tinggi wajib manerapkan Manajemen Risiko untuk seluruh 8 

kategori risiko yaitu Risiko Kredit, Risiko Pasar, Risiko Likuiditas, Risiko Operasional, Risiko Kepatuhan, Risiko Hukum, Risiko Reputasi, dan Risiko Stratejik.

Pada dasarnya jenis risiko yang dihadapi bank dapat dibagi dalam 2 (dua) kelompok besar, yaitu (Kasmir, 2000):

\section{Risiko Finansial}

Risiko finansial terkait dengan kerugian langsung berupa hilangnya sejumlah uang akibat risiko yang terjadi, risoko tersebut antara lain risiko operasional, risiko hukum, risiko kredit, risiko likuiditas, risiko reputasi dan risiko pasar.

\section{Risiko Non Finansial}

Risiko non financial terkait kerugian yang tidak dapat dikalkulasikan secara jelas jumlah uang yang hilang. Dampak financial dari risiko non Financial tidak langsung dapat dirasakan dan tidak langsung dapat membuat bank menjadi mgi, namun pada gilirannya risiko non financial beipotensi untuk menimbulkan kerugian financial, risiko tersebut antara lain risiko reputasi, risiko kepatuhan dan risiko stratejik.

\section{Hasil Dan Pembahasan}

\section{A. Penerapan Manajemen Risiko Pada Pemberian Kredit Perbankan Sebagai Prinsip Kehati-Hatian Bank}

Kegiatan usaha Bank selalu dihadapkan pada risiko-risiko yang berkaitan erat dengan fungsinya sebagai lembaga intermediary keuangan, terutama risiko dalam pemberian kredit yang mempunyai dampak cukup besar bagi kelangsungan usaha bank. Pesatnya perkembangan lingkungan eksternal dan internal perbankan juga menyebabkan semakin kompleksnya risiko kegiatan usaha perbankan. Oleh karena itu, agar mampu beradaptasi dalam lingkungan bisnis perbankan, Bank dituntut untuk menerapkan Manajemen Risiko.

Melalui penerapan Manajemen Risiko, Bank diharapkan dapat mengukur dan mengendalikan Risiko yang dihadapi dalam melakukan kegiatan usahanya dengan lebih baik. Selanjutnya, penerapan Manajemen Risiko yang dilakukan perbankan akan mendukung efektivitas kerangka pengawasan Bank berbasis Risiko yang dilakukan oleh Otoritas Jasa Keuangan. Upaya penerapan Manajemen Risiko dimaksud tidak hanya ditujukan bagi kepentingan Bank tetapi juga bagi kepentingan nasabah. Salah satu aspek penting dalam melindungi kepentingan nasabah dan dalam rangka pengendalian Risiko adalah transparansi informasi terkait produk atau aktivitas Bank.

Penerapan Manajemen Risiko dapat bervariasi antara satu Bank dengan Bank lain sesuai dengan tujuan, kebijakan usaha, ukuran dan kompleksitas usaha, kemampuan keuangan, infrastruktur pendukung serta kemampuan sumber daya manusia. Otoritas Jasa Keuangan menetapkan ketentuan ini sebagai standar minimal yang harus dipenuhi oleh perbankan Indonesia dalam menerapkan Manajemen Risiko. Dengan ketentuan ini, Bank diharapkan mampu melaksanakan seluruh aktivitasnya secara terintegrasi dalam suatu sistem pengelolaan Risiko yang akurat dan komprehensif, khususnya dalam

kegiatan usaha bank dalam penyaluran dana melalui kredit.

Pemberian kredit oleh bank kepada nasabah karena adanya kepercayaan setelah dilakukan analisis yang mendalam dan seksama terhadap itikad baik dan kemampuan serta kesanggupan calon debitur untuk melunasi utangnya sesuai dengan yang diperjanjikannya. Pemberian Kredit berarti 
memberikan kepercayaan kepada debitur oleh bank meskipun kepercayaan tersebut mengandung risiko yang tinggi. Setiap pemberian kredit bank harus memperhatikan prinsip kehati-hatian dan asas perbankan yang sehat, baik secara internal maupun secara eksternal. Secara eksternal sebelum dibuat perjanjian kredit bank selalu melakukan penilaian dari berbagai aspek, dengan menerapkan ketentuan Pasal 8 dan penjelasannya dalam Undang-undang Perbankan, bank wajib mempunyai keyakinan akan kemampuan debitur untuk mengembalikan kredit pada waktunya, seperti yang telah diperjanjikan.

Praktik perbankan sebelum menyalurkan kredit melakukan penilaian terhadap lima aspek kepada debitur atau yang kenal dengan The Five C 's of Credit Analysis (analisa 5C) yaitu: character, watak atau kepribadian debitur merupakan suatu unsur penting dalam pemberian kredit, yang dimaksudkan dengan watak adalah sifat pribadi yang baik, jujur dari calon debitur, yaitu mereka yang selalu menepati janjinya dan berupaya mencegah perbuatan yang tercela, dan mempunyai rasa tanggung jawab. Dalam hal ini perlu ketelitian dan kecermatan analisa kredit untuk meneliti daftar riwayat hidup calon debitur, bagaimana reputasi dilingkungan usahanya. Capacity, titik sasaran penilaian debitur adalah kemampuan mengendalikan usaha pada waktu ekonomi mengalami kelesuan. Prospek usaha di masa depan, produksi dan pemasaran, juga bahan baku, peralatan kerja, administrasi keuangan, bahkan kemampuan merebut pasar ikut di nilai bank. Aspek selanjutnya adalah Capital, untuk memperoleh kredit calon debitur harus memiliki modal terlebih dahulu, jumlah dan struktur modal calon debitur harus dapat diteliti dan diketahui tingkat rasio dan solvabilitasnya. Bank tidak dapat memberikan kredit kepada pengusaha tanpa modal sama sekali. Collateral, jaminan biasanya diartikan dengan harta benda milik debitor yang dijadikan jaminan atas piutangnya. Mengingat kredit selalu dibayangi oleh risiko, untuk antisipasi timbulnya risiko ini diperlukan jaminan sebagai sarana pengaman atas risiko yang mungkin timbul atas cidera janjinya nasabah dikemudian hari. Dan Condition of economic, kondisi atau situasi yang memberikan dampak positif kepada usaha calon debitur atau sebagaimana disebutkan dalam penjelasan Pasal 8 Undang-undang Perbankan yaitu hubungan faktor ekonomi makro terhadap risiko produknya. Kondisi ekonomi secara umum serta kondisi pada sektor usaha si pememohon kredit perlu mendapat perhatian dari pihak bank untuk memperkecil risiko yang mungkin timbul akibat kondisi ekonomi. Kondisi ini dapat terpengaruh oleh keadaan sosial, politik dan ekonomi dari suatu periode tertentu dan perkiraan yang akan teijadi pada waktu mendatang.

Secara internal imlementasi prinsip kehati-hatian bagi bank adalah Sumber Daya Manusia (SDM) bank adalah dengan menerapkan Prinsip Manajemen Risiko Perbankan. Perbankan Indonesia terus mengalami pembahan bentuk dan karakter secara signifikan. Kebijakan-kebijakan otoritas perbankan, tekanan kompetisi dalam pasar perbankan dan keuangan serta tuntutan kinerja dan efisiensi bisnis dari para stakeholders yang semakin dinamis menyebabkan bank harus dikelola secara proaktif terhadap kondisi dan potensi bisnis.

Bank wajib menerapkan Manajemen Risiko secara efektif, baik untuk Bank secara individual maupun untuk Bank secara konsolidasi dengan perusahaan anak. Bank Umum Konvensional menerapkan Manajemen Risiko yang mencakup 8 risiko, yaitu risiko kredit, risiko pasar, risiko likuiditas, risiko operasional, risiko hukum, risiko reputasi, risiko stratejik, dan risiko kepatuhan. Sementara itu, kegiatan usaha perbankan syariah tidak terlepas dari risiko yang dapat mengganggu kelangsungan bank, dan untuk mengelola risiko tersebut wajib menerapkan manajemen risiko secara individu dan secara konsolidasi sesuai dengan kegiatan usaha perbankan syariah. Penerapan Manajemen Risiko pada perbankan Syariah disesuaikan dengan tujuan, kebijakan usaha, ukuran, dan kompleksitas usaha serta kemampuan Bank. Berdasarkan Peraturan Otoritas Jasa Keuangan Nomor 65 
/POJK.03/2016 Tentang Penerapan Manajemen Risiko Bagi Bank Umum Syariah Dan Unit Usaha Syariah, mencakup Risiko Kredit, Risiko Pasar, Risiko Likuiditas, Risiko Operasional, Risiko Hukum, Risiko Reputasi, Risiko Stratejik, Risiko Kepatuhan, Risiko Imbal Hasil (Rate of Return Risk) dan Risiko Investasi (Equity Investment Risk).

Ruang lingkup penerapan Manajemen Risiko paling sedikit mencakup, antara lain pengawasan aktif Direksi dan Dewan Komisaris, yang merupakan garis pertahanan utama untuk mendapat kepastian bahwa bank yang di pimpinnya tersebut berjalan secara sehat dan mematuhi semua ketentuan hukum maupun regulasi yang berlaku. Dalam rangka melaksanakan wewenang dan tanggung jawab Direksi harus memiliki pemahaman yang memadai mengenai Risiko yang melekat pada seluruh aktivitas fungsional Bank dan mampu mengambil tindakan yang diperlukan sesuai dengan profil Risiko Bank.

Selanjutnya kecukupan kebijakan dan prosedur Manajemen Risiko serta penetapan limit Risiko, paling sedikit memuat, penetapan Risiko yang terkait dengan produk dan transaksi perbankan, penetapan penggunaan metode pengukuran dan sistem informasi Manajemen Risiko, penentuan limit dan penetapan toleransi Risiko, penetapan penilaian peringkat Risiko, penyusunan rencana darurat (contingency plan) dalam kondisi terburuk (worst case scenario) ؛dan penetapan sistem pengendalian intern dalam penerapan Manajemen Risiko. Sedangkan prosedur Manajemen Risiko dan penetapan limit Risiko wajib disesuaikan dengan tingkat Risiko yang akan diambil (risk appetite) terhadap Risiko Bank.

Dalam memenuhi kecukupan proses identifikasi, bank perlu mneumpulkan dan mengakumulasi data mengenai peristiwa, termasuk kerugian yang pernah terjadi di masa lalu, dengan kata lain di dasarkan pada pengalaman kerugian bank yang pernah terjadi. Pengukuran dan pemantauan risiko bank perlu menetapkan obot risiko yang di lihat dari tingkat kemungkinan terjadi dan dampak risiko yang dinilai. Limit risiko pemantauan tidak hanya ditujukan kepada transaksi yang melampaui limit atau kegiatan yang menyimpang dari garis kebijakan yang telah ditetapkan. Sistem informasi Manajemen Risiko dan pengendalian Risiko intern secara efektif terhadap pelaksanaan kegiatan usaha dan operasional pada seluruh jenjang organisasi Bank, dan mampu secara tepat 
waktu mendeteksi kelemahan dan penyimpangan yang terjadi.

Kategori risiko terkait dengan penyaluran dana melalui kredit antara lain adalah risiko kredit. Potensi peminjam atau nasabah debitur akan gagal berkaitan dengan kemampuan untuk memenuhi kewajibannya sesuai dengan kesepakatan dalam peijanjian kredit. Risiko ini disebabkan debitur gagal melaksanakan isi perjajian kredit, gagal memilih calon debitur dalam proses bemberian kredit SDM bank terkecoh dengan penampilan calon debitur, dalam hal ini pentingnya menerapkan prinsip $5 \mathrm{C}$. Untuk sebagian besar bank, penyaluran kredit merupakan sumber timbulnya risiko kredit yang paling besar, tinggi rendahnya risiko kredit di pengaruhi oleh beberapa faktor antara lain konsentrasi kredit, counterparty credit risk, dan settlement risk. Risiko konsentrasi kredit merupakan Risiko yang timbul akibat terkonsentrasinya penyediaan dana kepada 1 (satu) pihak atau sekelompok pihak, industri, sektor, dan/atau area geografis tertentu yang berpotensi menimbulkan kerugian cukup besar yang dapat mengancam kelangsungan usaha Bank. Counterparty credit risk merupakan Risiko yang timbul akibat teijadinya kegagalan pihak lawan dalam memenuhi kewajibannya dan timbul dari jenis transaksi yang memiliki karakteristik tertentu, misalnya transaksi yang dipengaruhi oleh pergerakan nilai wajar atau nilai pasar. Settlement risk merupakan Risiko yang timbul akibat kegagalan penyerahan kas dan/atau instrumen keuangan pada tanggal penyelesaian (settlement date) yang telah disepakati dari transaksi penjualan dan/atau pembelian instrumen keuangan.

Faktor lainnya adalah kualitas analis kredit serta proses pemutusannya biasanya ada keterkaitan dengan orang dalam, pemantauan atas penggunaan kredit oleh debitur, kualitas pengikatan jaminan serta kondisi perekonomian secara keseluruhan. Risiko ini harus dimengerti, di ukur dan diidentifikasi sebelum suatu fasilitas di berikan kepada nasabah debitur. Untuk itu perlu dilakukan penilaian kepada calon nasabah debitur atas hal-hal sebagai berikut: karakter dan reputasi debitur di pasar, kepemilikan dan pengelolaan manajemen yang baik, colateral yang di berikan debitur memenuhi perdyaratan pengikatan jamina serta kondisi ekonomi yang terjadi pada saat diberikannya fasilitas seperti persaingan, jenis produk yang dikelola nasabah debitur.

Risiko lain terkait dengan penyaluran dana melalui kredit adalah Risiko Hukum, eksposur yang timbul karena adanya kelemahan aspek yuridis, antara lain disebabkan karena adanya tuntutan hukum, ketiadaan peraturan perundang-undangan yang mendukung, perubahan undang-undang dan peraturan ekstern yang berakibat negatif pada kemampuan operasional. Kelemahan perikatan seperti tidak dipenuhinya syarat sahnya suatu peijanjian atau pengikatan agunan yang tidak sempurna.

Risiko berikutnya terkait dengan penyaluran dana melalui kredit Risiko Operasional, yaitu Risiko yang timbul akibat adanya ketidakeukupan atau tidak berfungsinya proses internal, kesalahan atau kecurangan manusia, kegagalan sistem dalam mencatat, membukukan dan melaporkan transaksi secara lengkap, benar dan tepat waktu, kegagalan dalam mematuhi ketentuan intern maupun regulasi yang berlaku, problem ektemal seperti perubahan regulasi atau adanya kejadian-kejadian eksternal yang mempengaruhi operasional Bank. Selanjutnya Risiko Reputasi, timbul antara lain karena adanya pemberitaan media atau publikasi dan rumor mengenai kegiatan usaha

Bank yang bersifat negatif, serta adanya strategi komunikasi Bank yang kurang efektif. Opini negatif publik terhadap operasional bank, sehingga mengakibatkan menurunnya jumlah nasabah bank tersebut atau menimbulkan biaya besar karena gugatan pengadilan atau merosotnya pendapatan bank.

\section{B. Kendala Dalam Penerapan Manajemen Risiko Perbankan}

Risiko selalu ada dunia bisnis, tidak ada bisnis yang tidak ada risiko, dalam menjalankan 
kegiatan usaha setiap saat harus bisa menanggung risiko, sehingga perlu di cari cara bagaimana meminimalisir suatu risiko. Khususnya perbankan di Indonesia yang susaha yang dilakukan oleh bank tidak menimbulkan kerugian yang melebihi kemampuan bank atau tidak mengganggu kelangsungan usaha bank.

Keberadaan Manajemen Risiko sangatlah penting dalam dunia perbankan. Esensi dari penerapan manajemen risiko adalah kecukupan prosedur dan metodologi pengelolaan risiko sehingga kegiatan usaha bank tetap dapat terkendali pada batas/limit yang dapat diterima serta menguntungkan bank. Mengingat perbedaan kondisi pasar dan struktur, ukuran serta kompleksitas usaha bank, maka tidak terdapat satu sistem manajemen risiko yang universal untuk seluruh bank sehingga setiap bank harus membangun sistem manajemen risiko sesuai dengan fungsi dan organisasi manajemen risiko pada bank.

Upaya peningkatan kualitas penerapan manajemen risiko tidak hanya ditujukan bagi kepentingan Bank tetapi juga bagi kepentingan nasabah. Salah satu aspek penting dalam melindungi kepentingan nasabah dan dalam rangka pengendalian risiko adalah transparansi informasi terkait produk atau aktivitas Bank. Selain itu peningkatan kualitas penerapan manajemen risiko diharapkan akan mendukung efektivitas kerangka pengawasan bank berbasis risiko.

Bank dituntut untuk menerapkan manajemen risiko agar mampu beradaptasi dengan lingkungan bisnis perbankan. Pengaturan manajemen risiko berdasarkan POJK No. 18 /POJK.03/2016 Tentang Penerapan Manajemen Risiko Bagi Bank Umum, merupakan standar minimal yang harus dipenuhi oleh perbankan Indonesia dalam menerapkan manajemen risiko, pedoman untuk dapat beroperasi secara lebih berhati- hati dalam ruang lingkup perkembangan kegiatan usaha dan operasional perbankan yang sangat pesat.

Penerapan Manajemen Risiko dapat bervariasi antara satu Bank dengan Bank lain sesuai dengan tujuan, kebijakan usaha, ukuran dan kompleksitas usaha, kemampuan keuangan, infrastruktur pendukung serta kemampuan sumber daya manusia. Namun masih terdapat beberapa hambatan dalam penerapan manajemen risiko, antara lain pada masa transisi bagi bank belum melakukan penyesuaian kebijakan manajemen risiko agar dapat sepenuhnya sejalan dengan ketentuan tentang penerapan manajemen risiko. Disamping itu sumber daya manusia yang terlibat dalam pemantauan penerapan manajemen risiko masih relatif kurang siap. Kualifikasi SDM yang belum jelas untuk setiap jenjang jabatan yang terkait dengan penerapan Manajemen Risiko, belum adanya kecukupan kuantitas dan kualitas SDM yang ada di Bank dan memastikan SDM dimaksud memahami tugas dan tanggung jawabnya, baik untuk unit bisnis, Satuan Kerja Manajemen Risiko maupun unit pendukung yang bertanggung jawab atas pelaksanaan Manajemen Risiko, sehingga proses pengawasan internal yang ada di bank belum sesuai dengan pedoman penerapan manajemen risiko perbankan.

Bagi perbankan nasional memang berat dalam menerapkan Basel II, tetapi hal tersebut merupakan suatu keharusan bagi perbankan nasional dalam mengikuti peraturan internasional. Mengingat fungsi perbankan sebagai lembaga intermediary dan mempunyai fungsi khusus sebagai lembaga kepercayaan merupakan suatu bisnis yang paling riskan, adanya permasalahan pada satu bank dapat mengakibatkan risiko yang sistemik yang dapat meruntuhkan perbankan lain sehingga secara otomatis akan menurunkan kegiatan perekonomian. Untuk mencegah hal buruk teijadi pada industri perbankan nasional diperlukan penanganan yang sangat spesifik dan dengan menerapkan prinsip kehati-hatian. Perlunya penguatan permodalan bagi perbankan nasional, juga mempersiapkan diri terhadap pemenuhan teknologi informasi (TI) dan sumber daya manusia yang 
baik.

\section{Kesimpulan Dan Saran}

\section{A. Kesimpulan}

1. Penerapan manajemen risiko pada pemberian kredit Perbankan sebagai prinsip kehati-hatian bank adalah mencakup pengawasan aktif Direksi dan Dewan Komisaris; kecukupan kebijakan dan prosedur Manajemen Risiko serta penetapan limit Risiko; kecukupan proses identifikasi, pengukuran, pemantauan, dan pengendalian Risiko, serta sistem informasi Manajemen Risiko; dan sistem pengendalian intem yang menyeluruh. Penyaluran kredit merupakan sumber timbulnya risiko kredit yang paling besar, tinggi rendahnya risiko kredit di pengaruhi oleh beberapa faktor antara lain konsentrasi kredit, counterparty credit risk, dan settlement risk. Risiko terkait dengan penyaluran kredit yaitu risiko kredit, risiko operasional, risiko hukum, dan risiko reputasi.

2. Kendala dalam penerapan manajemen risiko Perbankan, antara lain SDM yang terlibat dalam pemantauan penerapan manajemen risiko masih relatif kurang siap. Kualifikasi SDM yang belum jelas untuk setiap jenjang jabatan yang terkait dengan penerapan Manajemen Risiko.

\section{B. Saran}

Bank menerapkan Manajemen Risiko sesuai dengan tujuan, kebijakan usaha, ukuran dan kompleksitas usaha, serta kemampuan Bank. Perlunya pengembangan, dan pelatihan pegawai termasuk rencana suksesi manajerial serta remunerasi yang memadai untuk memastikan tersedianya pegawai yang kompeten di bidang Manajemen Risiko. Memastikan agar seluruh SDM memahami strategi, tingkat Risiko yang akan diambil dan toleransi Risiko, kerangka Manajemen Risiko yang telah ditetapkan Direksi kemudian disetujui oleh Dewan Komisaris serta dapat diimplementasikan secara konsisten dalam aktivitas yang ditangani. 


\section{DAFTAR PUSTAKA A. Buku-buku}

Ferry N. Idroes, Manajemen Risiko Perbankan, Jakarta, Rajawali Pers, 2006.

H.A.S. Mahmoedidn, 100 Penyebab Kredit Macet, Jakarta, Pustaka Sinar Harapan, 1995.

Hasanuddin Rahman, Aspek-aspek Hukum Pemberian Kredit Perbankan di Indonesia, Bandung, Citra Aditya Bakti, 1995.

Hermansyah, Hukum Perbankan Nasional Indonesia, Jakarta, Prenada Media Group, 2007.

Kasidi, Manajemen Risiko, Bogor, PT.Ghalia Indonesia, cetakan ke 2, 2014.

Kasmir, Bank dan Lembaga Keuangan lainnya (Edisi Baru), Jakarta, Raja Grafindo Persada, 2000.

Mariam Daras Badralzaman, Perjanjian Kredit Bank, Bandung, Alumni, 1983.

Masyud Ali, Manajemen Risiko, Jakarta, Rajawali Pers, 2004.

Muhamad Djuhamna, Hukum Perbankan di Indonesia, Bandung, PT.Citra Aditya Bakti, 2000.

Phillipe Jorion, Value At Risk, The New Benchmark For Controlling Market Risk, Chicago, Irwin, 1997.

Vaughan, 1978 dalam Herman Darmawi, Manajemen Risiko, Jakarta, Bumi Aksara, 2004.

\section{B. Peraturan Perundang-undangan}

Undang-Undang Dasar 1945

Undang-Undang No. 10 Tahun 1998 tentang perubahan Undang-undang No.7 Tahun 1992 tentang Perbankan

Peraturan Bank Indonesia (PBI) No. 5/8/PBI/2003 sebagaimana diubah dengan PBI No. 11/25/PBI/2009 tentang Penerapan Manajemen Risiko di Bank Umum.

Peraturan Otoritas Jasa Keuangan (POJK) No. 18/POJK.03/2016 tentang Penerapan Manajemen Risiko bagi Bank Umum.

Surat Edaran Otoritas Jasa Keuangan Nomor 34 /Seojk.03/2016 Tentang Penerapan Manajemen Risiko Bagi Bank Umum. 